\title{
[2.2](4,7)Isobenzofuranophanes - Synthesis, Characterisation, and Reactivity
}

\author{
Burkhard König $^{a}$, Sonja Ramm ${ }^{a}$, Peter Bubenitschek ${ }^{[\neq] a}$, Peter G. Jones ${ }^{[\neq l a}$, Henning Hopf ${ }^{\text {a }}$, Burkhard Knieriem ${ }^{b}$, \\ and Armin de Meijere*b
}

Institut für Organische Chemie der Technischen Universität Braunschweiga,

Hagenring 30, D-38106 Braunschweig, Germany

Institut für Organische Chemie der Universität Göttingen ${ }^{\mathrm{b}}$,

Tammannstraße 2, D-37077 Göttingen, Germany

Received May 9, 1994

Key Words: [2.2]Paracyclophanes, new derivatives of / Isobenzofuranophanes, preparation and cycloadditions

The isomeric Diels-Alder adducts 3, obtained by cycloaddition of tetraphenylcyclopentadienone to the 4,5:12,13-bis(oxanorbornadieno) [2.2]paracyclophanes syn,syn- and anti,syn-2 ${ }^{[*]}$, yield the unstable isobenzofuranophane 4 by consecutive extrusion of carbon monoxide and tetraphenylbenzene when heated to $180^{\circ} \mathrm{C}$. The molecular ion of 4 was observed in the EI mass spectrum. The stable tetraphenylsubstituted analogue 10 was synthesized independently from the previously unknown 4,5,12,13-tetrabenzoyl[2.2]paracyclophane (9). UV/Vis as well as fluorescence spectra and an $\mathrm{X}$-ray crystal structure analysis of $\mathbf{9}$ are reported.
[2.2]Furanophane ${ }^{[1]}$ has been used in cycloaddition reactions yielding bridged Diels-Alder adducts. Isobenzofu$\operatorname{ran}^{[2]}$ is a much more reactive diene for cycloadditions than furan due to the rearomatisation upon addition of the dienophile. A variety of methods have been developed to generate the unstable isobenzofuran and to trap it in situ as well as to observe it at low temperature or in highly diluted solutions $^{[3]}$. While engaged in designing new approaches to stair-like multilayered [2.2] paracyclophanes ${ }^{[4,5]}$, we have generated and characterised [2.2](4,7)isobenzofuranophane (4) and also prepared its stable tetraphenyl-substituted derivative $\mathbf{1 0}$.

4,5,12,13-Tetrabromo[2.2]paracyclophane (1), easily prepared from commercially available [2.2]paracyclophane, can be applied as a new bis-aryne equivalent ${ }^{[4]}$. The in situ-trapping of the corresponding bis-aryne with furan yields the two products syn,syn-2 ${ }^{[*]}$ and anti,syn-2 (ratio $\left.1: 1\right)^{[4]}$. This mixture of isomeric compounds 2 reacts with two equivalents of tetraphenylcyclopentadienone in refluxing benzene to yield the insoluble Diels-Alder adducts $3^{[5]}$ as a mixture of four diastereomers. When heated in $o$-dichlorobenzene solution or neat to $180^{\circ} \mathrm{C}$, extrusion of carbon monoxide occurs, and isobenzofuran moieties are formed on both decks of the molecule by retro-Diels-Alder reaction to yield $[2.2](4,7)$ isobenzofuranophane (4). The molecular ion of 4 was observed in the mass spectrum (EI and FD) of $\mathbf{3}$, and the molecular formula was confirmed by high-resolution mass spectrometry. The highly reactive 4 can be trapped in situ when 3 is heated in $o$-dichlorobenzene solution in the presence of $p$-benzoquinone to yield the two diastereomeric

[*] X-Ray crystal structure analysis.

[*] The stereochemical descriptors syn and anti refer to the orientation of the oxygen bridge in the oxabicyclo[2.2.1]heptadiene subunits with respect to the [2.2]paracyclophane skeleton.
Diels-Alder adducts $s y n, s y n-5$ and anti,syn-5 (ratio undetermined).

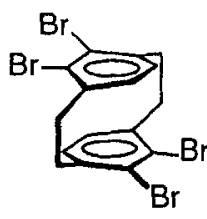

1

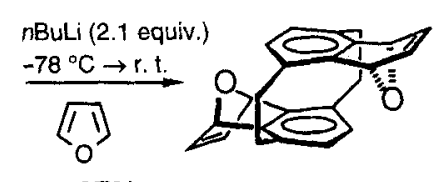

$27 \%$

syn,syn-2

+ anti,syn-2

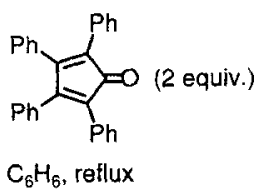

$31 \%$

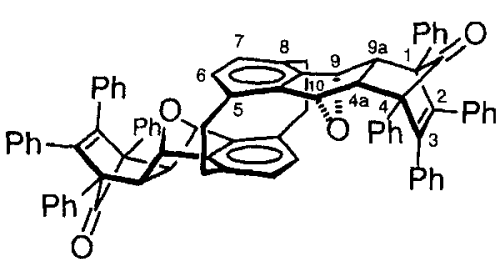

3 (mixture of stereoisomers)

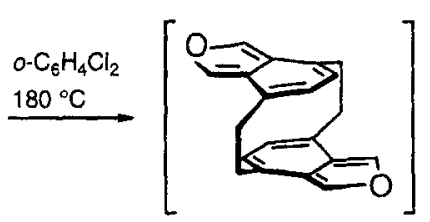

4
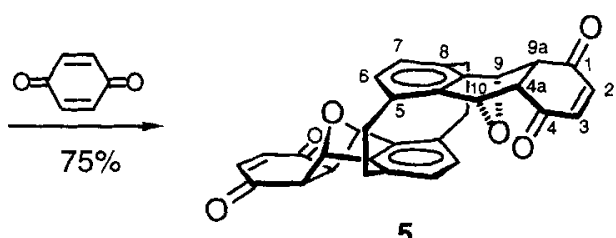

5 
The stability of the reactive isobenzofuran is increased by phenyl substituents, e.g. in 1,3-diphenylisobenzofuran ${ }^{[6]}$. Accordingly, 1,1',3,3'-tetraphenyl[2.2](4,7)isobenzofuranophane (10) was expected to be a stable compound. The logical precursor of 10, 4,5,12,13-tetrabenzoyl[2.2]paracyclophane (9), was prepared in 64\% yield from dibenzoylacetylene (7) and 1,2,4,5-hexatetraene (biallene) (6) by adaption of the procedure of Hopf et al. ${ }^{[7]}$ for the preparation of [2.2]paracyclophane-4,5, 12,13-tetracarboxylate.

Suitable crystals for X-ray structure analysis of 9 (see Figure 1) were obtained by slow concentration of its dichloromethane solution. The molecule of 9 possesses a crystallographic inversion centre. The torsional angles between the carbonyl and phenyl groups are $-21.1^{\circ}$ for $\mathrm{O} 1-\mathrm{C} 9-\mathrm{C} 10-\mathrm{C} 15$ and $163.6^{\circ}$ for $\mathrm{O} 2-\mathrm{C} 16-\mathrm{C} 17-\mathrm{C} 18$. The values for the corresponding angles between the carbonyl groups and the phane benzene rings are $120.2^{\circ}$ for $\mathrm{O} 1-\mathrm{C} 9-\mathrm{C} 3-\mathrm{C} 4$ and $-46.5^{\circ}$ for $\mathrm{O} 2-\mathrm{C} 16-\mathrm{C} 4-\mathrm{C} 3$.

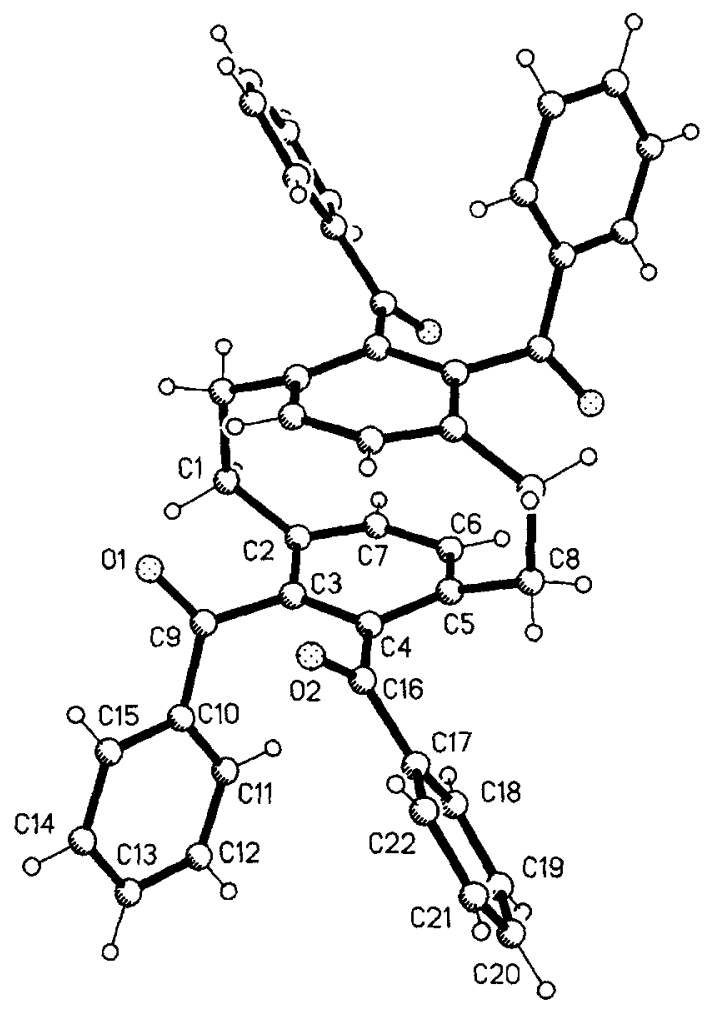

Figure 1. Molecular structure of compound 9 in the crystal ${ }^{[8]}$. Radii are arbitrary. Only the asymmetric unit is numbered. Selected bond lengths [pm]: $\mathrm{C}(1)-\mathrm{C}\left(8^{\prime}\right)$ 157.9(3), $\mathrm{C}(1)-\mathrm{C}(2)$ 151.5(3), $\mathrm{C}(3)-\mathrm{C}(9)$ $150.0(3), \mathrm{C}(9)-\mathrm{C}(10) 149.4(3), \mathrm{C}(9)-\mathrm{O}(1) 121.8(3)$; bond angles [ $\left.{ }^{\circ}\right]$ : $\mathrm{C}(3)-\mathrm{C}(9)-\mathrm{C}(10) 118.1(2), \mathrm{C}(3)-\mathrm{C}(9)-\mathrm{O}(1) 121.2(2), \mathrm{C}(5)-\mathrm{C}(8)-$ $\mathrm{C}\left(1^{\prime}\right)$ 112.3(2): dihedral angles $\left[{ }^{\circ}\right): \mathrm{C}(1)-\mathrm{C}(2)-\mathrm{C}\left(8^{\prime}\right)-\mathrm{C}\left(5^{\prime}\right) 4.9$, $\mathrm{C}(10)-\mathrm{C}(9)-\mathrm{C}(3)-\mathrm{C}(4)-64.9, \mathrm{C}(17)-\mathrm{C}(16)-\mathrm{C}(4)-\mathrm{C}(3) \quad 132.7$; bending of para-bridged benzene rings: angle between axis $\mathrm{C}(1)-\mathrm{C}(2)$ $[C(5)-C(8)]$ and plane $C(3)-C(7)-C(4)-C(6) 20$ [25], angle between plane $\mathrm{C}(2)-\mathrm{C}(3)-\mathrm{C}(7)[\mathrm{C}(4)-\mathrm{C}(5)-\mathrm{C}(6)]$ and plane $C(3)-C(7)-C(4)-C(6) 12[13]$

The nearly orthogonal orientation of the benzoyl substituents with respect to the cyclophane unit in $\mathbf{9}$ is reflected in the UV spectrum $\left[\lambda_{\max }(\lg \varepsilon)=253 \mathrm{~nm}(4.56), 280(4.16\right.$, sh), 320 (3.56) in tetrahydrofuran, 251 (4.54), 280 (4.17, sh), 318 (3.58) in acetonitrile] which shows mainly the absorp- tion of a carbonyl-substituted benzene like acetophenone $\left[\lambda_{\max }(\lg \varepsilon)=243 \mathrm{~nm}(4.11), 279(3.08), 315(1.74)\right]$ or benzaldehyde $\left[\lambda_{\max }(\lg \varepsilon)=242 \mathrm{~nm}(4.15), 280\right.$ (3.15), 328 (1.74)]. The considerable increase in intensity for the $\mathrm{n} \rightarrow$ $\pi^{*}$ transition near $320 \mathrm{~nm}$ most probably results from better overlap between the $n$ orbitals of the twisted carbonyl groups and the paracyclophane $\pi$ system, thus facilitating the electronic transition. Excitation of 9 in acetonitrile at $250 \mathrm{~nm}$ to only very weak fluorescence near $340 \mathrm{~nm}$ ([2.2]paracyclophane: $351 \mathrm{~nm}$ ), probably due to reabsorption of photons from the $S_{1} \rightarrow S_{0}$ transition by the relatively strong and broad $n \rightarrow \pi^{*}$ band of 9 .

Reduction of 9 with $\mathrm{LiAlH}_{4}$ in tetrahydrofuran and subsequent treatment of the resulting tetrol with acetic anhydride $^{[9]}$ gave 10 in $50 \%$ yield. The diphenylisobenzofuran moieties in 10 both readily cycloadd dienophiles like $N$-phenylmaleinimide and in situ generated dehydrobenzene to give the double Diels-Alder adducts 11 and $\mathbf{1 2}^{[10]}$, respectively, as mixtures of the syn,syn and anti,syn isomers.

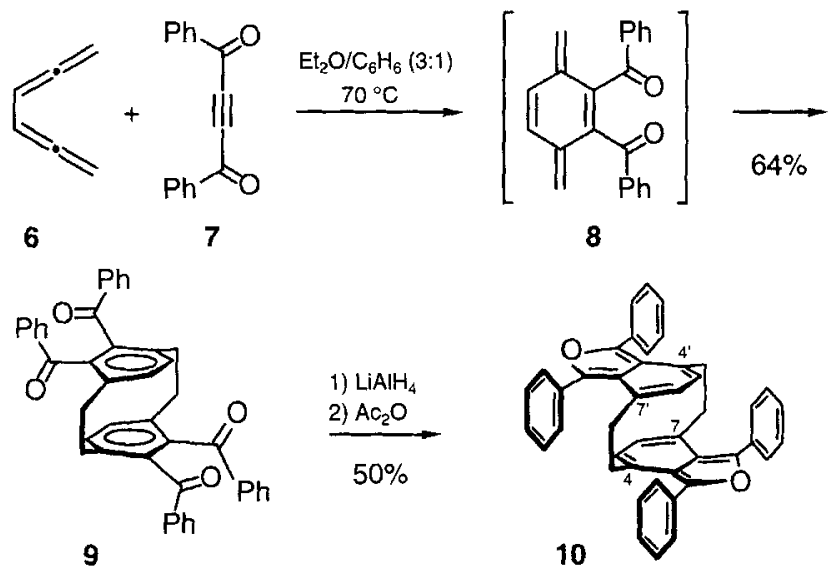

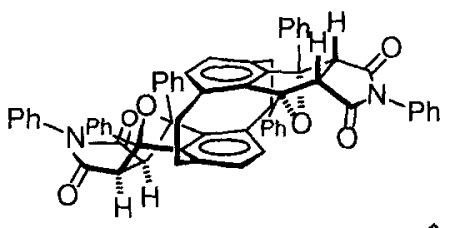

11
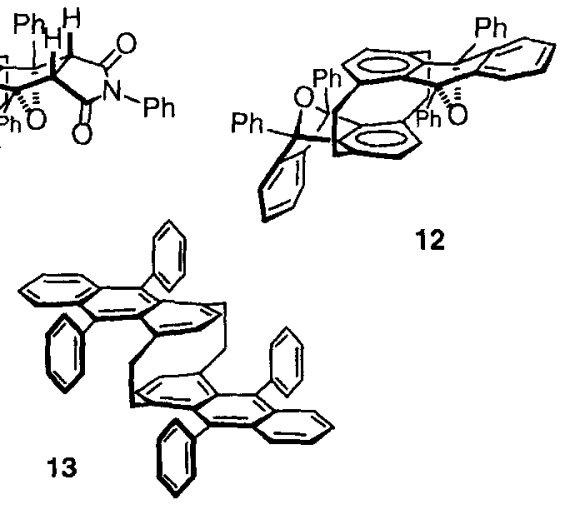

12

Both isobenzofuranophanes 4 and $\mathbf{1 0}$ can be envisaged as starting materials for extended [2.2]bisarenophanes like $13^{[4]}$ and even multilayered [2.2]paracyclophanes with a stair-like structure.

This work was supported by the Deutsche Forschungsgemeinschaft, the Volkswagen-Stiftung, and the Fonds der Chemischen Industrie as well as the BASF $A G$, Hoechst $A G$, Bayer $A G$, and Chemetall $\mathrm{GmbH}$ by generous gifts of chemicals. B. König is indebted to the Studienstiftung des deutschen Volkes for a graduate scholarship. 


\section{Experimental}

${ }^{1} \mathrm{H}$ NMR: Bruker WM 270 and AM 400; $\delta=0$ for tetramethylsilane as internal standard, $\delta=7.26$ for chloroform. $-{ }^{13} \mathrm{C}$ NMR: Bruker WM 270 and AM 400; $\delta=77$ for $\left[D_{1}\right]$ chloroform; the multiplicity of the signals was determined by the DEPT technique and quoted as $(+)$ for $\mathrm{CH}_{3}$ and $\mathrm{CH}$ groups, (-) for $\mathrm{CH}_{2}$ and $\left(\mathrm{C}_{\text {quat }}\right)$ for quaternary carbons. - IR: Nicolet 320 FT-IR. - MS: Finnigan MAT 8430. - UV/Vis and fluorescence: Cary 219 (Varian) and Perkin-Elmer MPF-44A. - Melting points: Hot-plate microscope, uncorrected. - Column chromatography (CC): Merck silica gel 60, 70-230 mesh; PE (60/70) stands for petroleum ether with a boiling range of $60-70^{\circ} \mathrm{C}$. - TLC was carried out on silica gel-coated aluminium sheets (Merck $\mathrm{F}_{254}$ ).

$1,4,4 a, 9,9 a, 10,1^{\prime}, 4^{\prime}, 4 a^{\prime}, 9^{\prime}, 9 a^{\prime}, 10^{\prime}$-Dodecahydro-1,2,3,4,1',2',

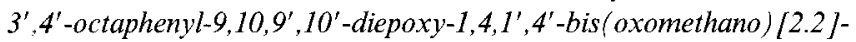
(5,8) anthracenophane (3): $500 \mathrm{mg}(1.47 \mathrm{mmol})$ of syn,syn-lanti,syn-2 and $1.13 \mathrm{~g}(2.94 \mathrm{mmol})$ of tetraphenylcyclopentadienone were refluxed in $100 \mathrm{ml}$ of benzene for $2 \mathrm{~d}$, during which time the colourless product precipitated. The reaction mixture was concentrated in vacuo to 30 $\mathrm{ml}$, the precipitate was collected on a filter, washed with $50 \mathrm{ml}$ of hot ethanol and dried in vacuo to yield $500 \mathrm{mg}(31 \%)$ of 3 as a colourless solid, m.p. $185^{\circ} \mathrm{C}$ (dec.). - IR (KBr): $\tilde{v}=3055 \mathrm{~cm}^{-1}, 1775,1604$, 1078. $-{ }^{1} \mathrm{H}$ NMR $\left(250 \mathrm{MHz}, \mathrm{CDCl}_{3}\right): \delta=3.00(\mathrm{~s}, 4 \mathrm{H}), 3.30(\mathrm{~m}$, $8 \mathrm{H}), 5.62(\mathrm{~s}, 4 \mathrm{H}), 6.35(\mathrm{~s}, 4 \mathrm{H}), 6.90-7.40(\mathrm{~m}, 40 \mathrm{H}) .-\mathrm{MS}(70 \mathrm{eV})$, $m / z(\%): 382(100)$ [tetraphenylbenzene], 288 (38) [4]. - MS (FD), $m / z(\%): 698(10), 382(100), 288(30) .-\mathrm{C}_{20} \mathrm{H}_{16} \mathrm{O}_{2}$ : calcd. for $\left[\mathrm{M}^{+}\right]$ of 4288.1150 ; found 288.1143 (MS).

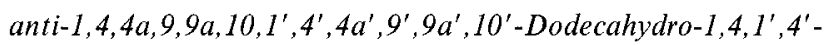

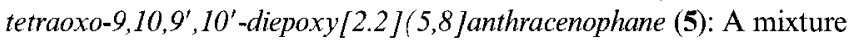
of $30 \mathrm{mg}(0.027 \mathrm{mmol})$ of 3 and $50 \mathrm{mg}(0.46 \mathrm{mmol})$ of $p$-benzoquinone in $10 \mathrm{ml}$ of dichlorobenzene was heated under nitrogen at $180^{\circ} \mathrm{C}$ for $5 \mathrm{~min}$. After cooling to room temp. $20 \mathrm{ml}$ of $\mathrm{PE}(60 / 70)$ was added, the precipitated crystals were filtered off and dried in vacuo yielding $10 \mathrm{mg}(75 \%)$ of 5 . $-{ }^{1} \mathrm{H}$ NMR $\left(250 \mathrm{MHz}, \mathrm{CDCl}_{3}\right): \delta=2.80-3.30$ $(\mathrm{m}, 10 \mathrm{H}), 3.52(\mathrm{~m}, 2 \mathrm{H}), 5.45(\mathrm{~s}, 2 \mathrm{H}), 5.60(\mathrm{~m}, 2 \mathrm{H}), 5.92(\mathrm{~s}, 2 \mathrm{H}), 6.20$ (s, 2H), $6.35(\mathrm{~s}, 2 \mathrm{H}), 6.85(\mathrm{~s}, 2 \mathrm{H})$.

4,5,12,13-Tetrabenzoyl [2.2 Jparacyclophane (9): A mixture of $180 \mathrm{ml}$ (108 mmol, approx. $0.6 \mathrm{M}$ of 1,2,4,5-hexatetraene (6) in diethyl ether and $18 \mathrm{~g} \mathrm{(77} \mathrm{mmol)} \mathrm{of} \mathrm{dibenzoylacetylene} \mathrm{(7)} \mathrm{in} 60 \mathrm{ml}$ of benzene was heated in a distillation apparatus with a 40 -cm Vigreux column for 5 $\mathrm{h}$ at $45^{\circ} \mathrm{C}$ and for $20 \mathrm{~h}$ at $70^{\circ} \mathrm{C}$. The cold reaction mixture was filtered, the solid residue recrystallized from toluene and dried in vacuo to yield $15.3 \mathrm{~g}(64 \%)$ of 9 as a colourless solid, m.p. $>280^{\circ} \mathrm{C}$. - IR $(\mathrm{KBr}) \tilde{\mathrm{v}}=1671 \mathrm{~cm}^{-1}, 1594,1448,1269,692 .-\mathrm{UV}(\mathrm{THF}): \lambda_{\max }(\mathrm{lg}$ $\varepsilon)=253 \mathrm{~nm}$ (4.564), 280 (4.16, sh), 320 (3.556); (acetonitrile): $\lambda_{\max }$ $(\lg \varepsilon)=251$ (4.538), $280(4.17, \mathrm{sh}), 318$ (3.580). - ${ }^{1} \mathrm{H}$ NMR $(250$ $\left.\mathrm{MHz}, \mathrm{CDCl}_{3}\right): \delta=2.90(\mathrm{~m}, 8 \mathrm{H}), 7.10-7.55(\mathrm{~m}, 24 \mathrm{H}) .-{ }^{13} \mathrm{C} \mathrm{NMR}$ $\left(62.5 \mathrm{MHz}, \mathrm{CDCl}_{3}\right): \delta=33.82(-), 127.96(+), 129.20(+), 132.67$ $(+), 134.74(+), 137.02\left(\mathrm{C}_{\text {quat }}\right), 138.32\left(\mathrm{C}_{\text {quat }}\right), 139.91\left(\mathrm{C}_{\text {quat }}\right), 196.72$ $\left(\mathrm{C}_{\text {quat }}\right) .-\mathrm{MS}(70 \mathrm{eV}), \mathrm{m} / \mathrm{z}(\%): 624(100)\left[\mathrm{M}^{+}\right] .-\mathrm{C}_{44} \mathrm{H}_{32} \mathrm{O}_{4}(624.7)$ : calcd. C 84.59, H 5.16; found C 84.42, H 5.22.

$X$-Ray Structure Determination of Compound $9^{[8]}: \mathrm{C}_{44} \mathrm{H}_{32} \mathrm{O}_{4}, M=$ 624.70, triclinic, space group $P \overline{1}, a=91.4(4), b=983.1(4), c=$ $1040.3(5) \mathrm{pm}, \alpha=94.01(2), \beta=116.10(2), \gamma=106.32(2)^{\circ}, V=$ $0.7879(6) \mathrm{nm}^{3}, Z=1, \lambda\left(\right.$ Mo- $\left.K_{\alpha}\right)=0.71073 \AA, \mu=0.083 \mathrm{~mm}^{-1}$, $D_{\mathrm{x}}=1.314 \mathrm{Mg} \mathrm{m}^{-3}, F(000)=328, T=143 \mathrm{~K}$. A colourless prism (ca. $0.65 \times 0.30 \times 0.25 \mathrm{~mm}$ ) was mounted on a glass fibre in inert oil (type RS3000, donated by Fa. Riedel de Haën) and transferred to the cold gas stream of a Stoe STADI-4 diffractometer with a Siemens LT-2 low-temperature attachment. Cell constants were refined from $\pm \omega$ values of 52 reflections in the $2 \Theta$ range $20-23^{\circ}$. A total of 2980 intensities (2792 unique, $R_{\mathrm{int}}=0.0197$ ) were measured to $2 \Theta \leq 50^{\circ}$.
The structure was solved by direct methods and refined anisotropically on $F^{2}$ (program SHELXL-93, G. M. Sheldrick, University of Göttingen). Hydrogen atoms were included with a riding model. The final $w R\left(F^{2}\right)$ for all reflections was 0.123 , with a conventional $R(F)$ of 0.0487 , for 217 parameters.

anti-1,1',3,3'-Tetraphenyl [2.2](4,7) isobenzofuranophane (10): To $200 \mathrm{mg}(0.32 \mathrm{mmol})$ of 9 suspended in $110 \mathrm{ml}$ of anhydrous THF was added $40 \mathrm{mg}$ (1.05 mmol) of $\mathrm{LiAlH}_{4}$ at room temp., the mixture was stirred for an additional $10 \mathrm{~min}$, then evaporated to dryness in vacuo, $60 \mathrm{ml}$ of acetic anhydride was added to the residue, and the mixture was refluxed under nitrogen for $30 \mathrm{~min}$. After cooling to room temp. the precipitated solid was collected by filtration, washed with water ( 3 $\times 20 \mathrm{ml})$ and dried in vacuo to yield $95 \mathrm{mg}(50 \%)$ of $\mathbf{1 0}$ as a green solid. m.p. $>280^{\circ} \mathrm{C}$. - IR $(\mathrm{KBr}): \tilde{v}=2937 \mathrm{~cm}^{-1}, 956,760$. - UV (dichloromethane): $\lambda_{\max }(\lg \varepsilon)=252 \mathrm{~nm}$ (3.980), 343 (3.997), 439 (3.801). $-{ }^{1} \mathrm{H}$ NMR $\left(250 \mathrm{MHz}, \mathrm{CDCl}_{3}\right): \delta=2.05$ and $3.10(\mathrm{~m}, 8 \mathrm{H})$, $5.72(\mathrm{~s}, 4 \mathrm{H}), 7.10-7.80(\mathrm{~m}, 20 \mathrm{H}) .-\mathrm{MS}(70 \mathrm{eV}), m / z(\%): 592(38)$ $\left[\mathrm{M}^{+}\right], 296(100)\left[\mathrm{M}^{2+}\right]$.

Diels-Alder Reaction of $\mathbf{1 0}$ with $\mathrm{N}$-Phenylmaleinimide: $20 \mathrm{mg}(0.034$ mmol) of 10 and $24 \mathrm{mg}(0.14 \mathrm{mmol})$ of $N$-phenylmaleinimide were refluxed in $20 \mathrm{ml}$ of toluene for $30 \mathrm{~min}$, during this time the green fluorescence disappeared. The solvent was removed in vacuo, the solid residue washed with $20 \mathrm{ml}$ of dichloromethane and dried in vacuo to yield $19.5 \mathrm{mg}(61 \%)$ of compound 11 (mixture of syn,syn and anti,syn isomers, most probably with a ratio of $1: 1) .-{ }^{1} \mathrm{H}$ NMR $(250 \mathrm{MHz}$, $\left.\mathrm{CDCl}_{3}\right): \delta=1.70$ and $2.22(\mathrm{~m}, 8 \mathrm{H}), 3.95(\mathrm{~s}, 4 \mathrm{H}), 6.35(\mathrm{~s}, 4 \mathrm{H}), 6.48$ $(\mathrm{m}, 4 \mathrm{H}), 7.26,7.50$ and $8.35(\mathrm{~m}, 26 \mathrm{H}),-{ }^{13} \mathrm{C}$ NMR $(62.5 \mathrm{MHz}$, $\left.\mathrm{CDCl}_{3}\right): \delta=30.89(-), 56.76(+), 91.02\left(\mathrm{C}_{\text {quat }}\right), 126.53,127.29$, $127.78,128.46,128.72$ and $128.83(+), 131.14$ and $132.69\left(\mathrm{C}_{\text {quat }}\right)$, $135.50(+), 138.02,140.66$ and $173.14\left(\mathrm{C}_{\text {quat }}\right) .-\mathrm{MS}(70 \mathrm{eV}), \mathrm{m} / \mathrm{z}(\%)$ : $592(28), 173(100)$.

Diels-Alder Reaction of $\mathbf{1 0}$ with Dehydrobenzene: To a mixture of $50 \mathrm{mg}(0.084 \mathrm{mmol})$ of 10 and $400 \mathrm{mg}(1.70 \mathrm{mmol})$ of 1,2-dibromobenzene in $60 \mathrm{ml}$ of anhydrous THF was added dropwise at $-40^{\circ} \mathrm{C}$ $1.2 \mathrm{ml}(1.8 \mathrm{mmol})$ of $n$-butyllithium ( $1.5 \mathrm{M}$ solution in hexane) in 10 $\mathrm{ml}$ of hexane. The mixture was stirred for $20 \mathrm{~min}$ and then allowed to warm up to room temp., $2 \mathrm{ml}$ of methanol and $100 \mathrm{ml}$ of dichloromethane were added, and the organic phase was washed with water $(3 \times 50 \mathrm{ml})$, dried with $\mathrm{MgSO}_{4}$, and evaporated to dryness in vacuo. Chromatography of the residue on $50 \mathrm{~g}$ of silica gel (dichloromethane) yielded four fractions: I $\left(R_{\mathrm{f}}=0.9\right)$ 1,2-dibromobenzene, not isolated. - II $\left(R_{\mathrm{f}}=0.64\right): 15 \mathrm{mg}(24 \%)$ of $9,9^{\prime}, 10,10^{\prime}$-tetrahydro-9, $9^{\prime}, 10,10^{\prime}$ -

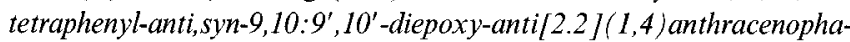
$n e^{[10]}$ (anti,syn-12). - III $\left(R_{\mathrm{f}}=0.46\right): 6 \mathrm{mg}(10 \%)$ of 9,9',10,10'-tetra-

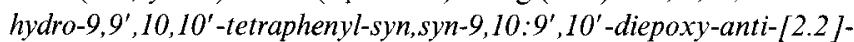
$(1,4)$ anthracenophane ${ }^{[10]}\left(\right.$ syn,syn-12), - IV $\left(R_{\mathrm{f}}=0.36\right): 15 \mathrm{mg}(28 \%)$ of 9 .

[1] [1a] H. E. Winberg, F. S. Fawcett, W. E. Mochel, C. W. Theobald, I. Am. Chem. Soc. 1960, 82, 1428-1435. - [1b] F. R. Holdren, M. R. Hixon, J. Am. Chem. Soc 1946, 68, $1198-1200 .-{ }^{[1 c]}$ L. A. Paquette, M. J. Wyvratt, H. C. Berk, R. E. Moerck, J. Am. Chem. Soc. 1978, 100, 5845-5855.

[2] A. R. Katritzky, C. W. Rees, Compr. Heterocycl. Chem. 1984, 4, 682-684.

[3] [3a] U. E. Wiersum, W. J. Mijs, J. Chem. Soc, Chem. Commun. 1972, 347-348. - ${ }^{[3 \mathrm{~b}]}$ H. Takeshita, A. Mori, S. Sano, Y. Fujise, Bull. Chem. Soc. Jpn. 1975, 48, 1661-1662.

${ }^{[4]}$ B. König, B. Knieriem, K. Rauch, A. de Meijere, Chem. Ber. 1993, $126,2531-2534$.

[5] For a review on multilayered stack structures see: P. M. Keehn, S. M. Rosenfeld, Cyclophanes I, II, Academic Press, New York, 1983. - Stair-like multilayered ferrocene-type complexes derived from anti-bis[2.2]indenophane have been reported: H. Hopf, F.-W. Raulfs, D. Schomburg, Tetrahedron 1986, 42, 1655-1663. 
[6] U. E. Wiersum, Aldrichimica Acta 1981, 14, 53-59.

[7] [7a] I. Böhm, H. Herrmann, K. Menke, H. Hopf, Chem. Ber. 1978, 111, 523-537. - [7b] H. Hopf, I. Böhm, J. Kleinschroth, Org. Synth. 1980, 60, 41-48.

${ }^{[8]}$ Full details of the structure determination have been deposited at the Fachinformationszentrum Karlsruhe, Gesellschaft für wissenschaftlich-technische Information $\mathrm{mbH}$, D-76344 Eggenstein-Leopoldshafen, Germany, from where this material may be obtained on quoting the full literature citation and the reference number CSD-58420.

[9] K. T. Pott, A. J. Elliott, Org. Prep. Proced. Int. 1972, 4, 269-272.

[10] Compound 12 has previously been prepared by cycloaddition of diphenylisobenzofuran to in situ generated 4,5:12,13-bis(dehydro[2.2]paracyclo)phane ${ }^{[4]}$ followed by deoxygenation. Spectroscopic data for the two samples were identical.

$[167 / 94]$ 